\title{
STUDI PENGEMBANGAN DAN PEMASARAN KASOAMI DI KELURAHAN WANCI KECAMATAN WANGI-WANGI KABUPATEN WAKATOBI
}

\author{
Wardana $^{1)}$, Muzuna ${ }^{1)}$ \\ Program Studi Agribisnis \\ Fakultas Pertanian \\ Universitas Muhammadiyah Buton, Baubau, Indonesia \\ Email: wardana@umbuton.ac.id
}

\begin{abstract}
Kasoami is a tradisional food in Wakatobi Regency which have to contend with modern food like rice. This study aims to determine the efforts made by Kasoami craftsmen in maintaining their business in the midst of competition with other food products and to figure out the development and marketing strategies of Kasoami. The collected data were analyzed descriptively and SWOT. The conclusions are: the efforts made by craftsmen in maintaining their business are learning to improve product quality, shelf life and good packaging of Kasoami which are equipped with production labels according to applicable standards. The product development strategies based on strengths and opportunities owned by craftsmen are: Promoting Kasoami as a quality and healthy product through online media; Collaborating with distributors and tourism agents; Providing excellent service to customers; Increasing the amount of production; Strategies based on utilizing opportunities to face weaknesses are craftsmen: Need to learn a good business management system; Need to learn to create a kasoami that has a unique and delicious taste; It is necessary to utilize a distributor agent; Need to get infrastructure assistance to increase production capacity from the government or private parties; Strategy for developing products based on strength to face threats are: Increase competitiveness and maintain quality; Reducing dependency on fuel oil; Increase product creativity and use of materials as efficiently as possible.
\end{abstract}

Keywords: development studies, kasoami, marketing, SWOT

\begin{abstract}
Abstrak
Kasoami adalah makanan tradisional di Kabupaten Wakatobi yang harus bersaing dengan makanan modern seperti nasi. Penelitian ini bertujuan untuk mengetahui upaya yang dilakukan oleh pengrajin kasoami dalam mempertahankan bisnis mereka di tengah persaingan dengan produk makanan lainnya dan untuk mengetahui strategi pengembangan dan pemasaran kasoami. Data yang terkumpul dianalisis secara deskriptif dan SWOT. Kesimpulannya adalah upaya yang dilakukan oleh pengrajin dalam mempertahankan bisnis mereka adalah belajar untuk meningkatkan kualitas produk, umur simpan dan kemasan yang baik dari Kasoami yang dilengkapi dengan label produksi sesuai dengan standar yang berlaku. Strategi pengembangan produk berdasarkan kekuatan dan peluang yang dimiliki oleh pengrajin adalah mempromosikan kasoami sebagai produk yang berkualitas dan sehat melalui media online, bekerja sama dengan
\end{abstract}


distributor dan agen pariwisata, memberikan layanan terbaik kepada pelanggan, meningkatkan jumlah produksi, strategi yang didasarkan pada pemanfaatan peluang untuk menghadapi kelemahan adalah pengrajin: perlu mempelajari sistem manajemen bisnis yang baik, perlu belajar membuat kasoami yang memiliki rasa unik dan lezat, diperlukan untuk menggunakan agen distributor, perlu mendapatkan bantuan infrastruktur untuk meningkatkan kapasitas produksi dari pemerintah atau pihak swasta, Strategi untuk mengembangkan produk berdasarkan kekuatan untuk menghadapi ancaman adalah: Meningkatkan daya saing dan menjaga kualitas, mengurangi ketergantungan pada bahan bakar minyak, tingkatkan kreativitas produk dan penggunaan bahan seefisien mungkin.

Kata kunci: strategi pengembangan, kasoami, pemasaran, SWOT

\section{PENDAHULUAN}

Kasoami adalah makanan tradisional yang populer di masyarakat Sulawesi Tenggara, khususnya wilayah Kesultanan Buton masa lampau (Kabupaten Wakatobi, Kota Baubau, Kabupaten Muna, Kabupaten Wakatobi dan Kabupaten Bombana) dan masyarakat Buton yang tersebar di kepulauan nusantara saat ini. Kasoami diolah menggunakan tepung ubi kayu, tepung gaplek, atau ubi kayu yang telah difermentasi. Kasoami dikonsumsi dengan ikan atau daging ayam. Untuk masyarakat Sulawesi Tenggara dan masyarakat asal Sulawesi Tenggara di kepulauan nusantara saat ini, mengkonsumsi kasoami kebanyakan dengan ikan sehingga kekurangan protein dan lemak dari kasoami dapat diatasi.

Banyak orang asing berdatangan dari berbagai Negara di Kabupaten Wakatobi saat ini. Bagi masyarakat lokal bila ada di antara orang asing (turis) yang datang, mereka selalu menyajikan kasoami khususnya kasoami pepe dan ternyata para turis tersebut sangat menikmatinya. Ini bukti bahwa masyarakat asing pun menyukai kasoami. Sehingga makanan tradisonal kasoami ini memiliki prospek yang baik untuk dipasarkan.

Masalah yang dihadapi pemasaran makanan tradisional adalah semakin banyaknya makanan modern yang masuk ke Indonesia, termasuk diantaranya beras dan roti, dapat menyebabkan punahnya makanan tradisional yang terganti kedudukannya, namun juga berpengaruh pada perekonomian para pedagang kasoami yang semakin menurun. Untuk menghadapi persaingan dengan produk makanan, maka para pedagang kasoami memerlukan beberapa upaya atau strategi pemasaran yang harus dilakukan agar produk makanan tradisional juga tetap menjadi khas dari daerahnya atau tidak mengalami kepunahan dan juga untuk mempertahankan perekonomian mereka agar tetap stabil.

Adapun tujuan penelitian ini adalah sebagai berikut: 1) Untuk mengetahui upaya apa saja yang dilakukan para pengrajin kasoami, untuk mempertahankan usahanya ditengah maraknya persaingan dengan produk makanan/kue modern di Kelurahan Wanci Kecamatan Wangi-Wangi Kabupaten Wakatobi. 2) Untuk mengetahui strategi pengembangan dan pemasaran produk kasoami yang dilakukan pengrajin kasoami di Kelurahan Wanci Kecamatan Wangi-Wangi Kabupaten Wakatobi. 


\section{METODE PENELITIAN}

Metode penentuan sampel pengrajin di Kelurahan Wanci Kecamatan WangiWangi Kabupaten Wakatobi dilakukan dengan metode Simple Random Sampling dengan memilih 30 pengrajin secara acak sebagai sampel dari 120 pengrajin sebagai populasi. Besar sampel tersebut dianggap mewakili populasi. Penentuan besar sampel yang hanya 30 pengrajin bertujuan untuk mempermudah dan mempercepat proses penelitian (Singarimbun dan Effendi, 1989).

Variabel yang diamati dalam penelitian ini yaitu: 1) Identitas responden adalah sebagai berikut: pendidikan, pengalaman berusaha, dan jumlah tanggungan keluarga; 2) Upaya pengrajin dan pedagang untuk mempertahankan usaha rumah tangga kasoami; 3) Kondisi sosial ekonomi pengrajin; 4) Jumlah produksi dan pendapatan; 5)Faktor internal usaha rumah tangga kasoami, yaitu kekuatan (strength) dan kelemahan (weakness), dan faktor eksternal usaha rumah tangga kasoami, yaitu peluang (Opportunities) dan ancaman (threat).

Indikator kekuatan yang digunakan adalah: produk berkualitas, produk sehat, cita rasa disukai, harga di pasar bersaing, produk tanpa bahan pengawet makanan, lokasi usaha rumah tangga kasoami strategis, modal sendiri dan bahan baku mudah didapatkan. Dan indikator Kelemahan meliputi: tidak memiliki sistem manajemen usaha rumah tangga kasoami, sedikitnya variasi bentuk dan cita rasa produk, minimnya kegiatan promosi, wilayah distribusi masih terbatas, minimnya modal yang dimiliki, kapasitas produksi masih terbatas, minimnya sarana dan prasarana operasional usaha rumah tangga kasoami, dan tidak adanya riset dan pengembangan produk.

Indikator peluang meliputi: bertambahnya populasi penduduk, perkembangan dunia internet, ketersediaan bahan baku yang melimpah, menjalin kerjasama dengan agen distributor, tingginya loyalitas kosumen terhadap produk usaha rumah tangga kasoami, pangsa pasar masih luas, dan perkembangan industri wisata. Dan indikator ancaman meliputi: kenaikan harga bahan bakar minyak, dibukanya pasar bebas, perubahan cuaca yang tidak stabil, fluktuasi nilai tukar rupiah, pola hidup masyarakat yang sudah modern, banyaknya produsen ritel makanan modern, banyaknya produk substitusi.

Data yang telah dikumpulkan di lapangan diolah dengan mentabulasikan dan seterusnya dipindahkan kedalam bentuk tabularis sesuai dengan kebutuhan, kemudian ditabulasi dan dianalisa dengan menggunakan analisis deskriptif dan analisis SWOT. Dengan analisis SWOT diharapkan dapat membantu mengatasi kelemahan dan ancaman, serta memaksimalkan kekuatan yang ada. Kekuatan yang dimiliki akan mampu memanfaatkan peluang pasar (Bradford, Duncan, dan Tarcy, 2004).

\section{HASIL DAN PEMBAHASAN}

\section{Pemasaran}

Pemasaran sangatlah penting dalam menjalankan usaha, pemasaran bisa dikatakan kata kunci dari setiap pelaksanaan usaha namun pemasaran juga tidak bisa berjalan lancar ketika tidak didukung oleh strategi yang jitu untuk memasarkan produksinya. Pengrajin selain menjual produknya sendiri dibantu anggota keluarganya, kadangkala menjual produknya pada pengecer. 


\section{Produk}

Meskipun banyak konsumen yang meminati dan membeli produk kasoami dari pengrajin kasoami ini, tetapi sedikitnya variasi, cita rasa, dan bentuk produk kasoami yang dihasilkan menyebabkan pangsa pasar dan permintaan produk pun stagnan hanya sekitar Kelurahan Wanci. Hal ini menyebabkan kerajinan kasoami kurang berkembangan. Strategi pengembangan produk hanya dengan mempertahankan cita rasa, mereka kurang berani untuk bereksperimen dengan cita rasa yang lain (baru), kecuali ada teman atau orang lain yang memberikan contoh keberhasilan memasarkan produk kasoami dengan cita rasa yang baru. Kesimpulannya bahwa dari segi produk para pengrajin kasoami belum pernah ada terobosan baru untuk membuat varian warna, ukuran, dan rasa. Nilai tambah dari produk kasoami yang ada adalah tidak menggunakan bahan pengawet untuk menjaga kualitas produknya dari segi kesehatan sehingga para wisatawan menyukainya.

\section{Tempat Pemasaran}

Pengrajin kasoami di Kelurahan Wanci menjual produknya, kemungkinan ada 4 tempat yaitu: pasar, rumah, dekat jembatan dan pelabuhan. Untuk jumlah besar maka penjualan dilakukan di rumah, pasar dan di jembatan yang merupakan tempat yang biasa dilalui oleh pengunjung yang masuk ke Kelurahan Wanci. Tempat ini menjadi pilihan penjual jika pasar telah tutup dan sepi sedangkan untuk dipelabuhan, penjual kasoami akan berjualan sesuai jadwal kedatangan kapal. Pengrajin kasoami biasanya juga menjual produknya tersebut pada pedagang pengecer yang berjualan di pelabuhan dan jembatan.

\section{Promosi}

Promosi yang dilakukan oleh pengrajin Kasoami sampai saat ini hanyalah dengan media mouth to mouth (mulut ke mulut) dari para konsumen yang sudah pernah membeli produk kasoami dari pengrajin kasoami tersebut. Kurangnya promosi yang dilakukan menyebabkan sedikit sekali masyakat di luar Kelurahan Wanci yang mengetahui keberadaan produk tersebut. Dari wawancara diatas maka bisa dikatakan secara umum pengrajin Kasoami tidak pernah melakukan terobosan promosi apa pun terkait dengan produknya. Kurangnya pengetahuan tentang bagaimana mempromosikan produk kasoami secara online dan waktu untuk mempromosikan tersebut menjadi alasan pengrajin untuk tidak mempromosikan produk kasoaminya secara online.

\section{Sistem pengelolaan keuangan}

Usaha kasoami yang dilakukan oleh pengrajin di Kelurahan Wanci dilakukan secara sederhana, termasuk system pengelolaan keuangannya. Biaya dan pendapatan pengrajin tidak dikelola terpisah dari biaya dan pendapatan lain. Dengan kata lain pengelolaan keuangan pengrajin tidak dilakukan secara serius. Keuntungan dari hasil penjualan kasoami atau hasil usaha lembih banyak digunakan untuk memenuhi kebutuhan hidup, hanya sedikit bahkan seringkali tidak ada uang yang digunakan untuk peningkatkan skala usaha.

\section{Deskripsi Faktor Internal dan Eksternal Usaha Kasoami}

Dalam rangka pengembangan industri kasoami di Kabupaten Wakatobi maka perlu kiranya dideskripsikan kondisi internal dan eksternal yang berpengaruh terhadap pengembangan industri kasoami ke depan, dengan mengidentifikasi kekuatan (strength), kelemahan (weaknees), peluang (oportunity), dan tantangan (treath) atau yang biasa disingkat SWOT yang dihadapi oleh pengrajin kasoami di Kelurahan Wanci Kecamatan Wangi-Wangi Kabupaten Wakatobi. 


\section{Kekuatan (Strength)}

Kekuatan yang dimiliki oleh pengolah kasoami adalah hasil produksi kasoami berkualitas dan cita rasa disukai sehingga senantiasa terjual habis, mengingat makanan tradisional ini sangat digemari oleh masyarakat Wakatobi karena dijadikan sebagai makanan pokok yang bernilai gizi tinggi dan enak. Kekuatan berikutnya adalah ketersediaan bahan baku, yaitu ubi kayu yang banyak tumbuh di Kabupaten Wakatobi. Selanjutnya adalah kasoami adalah produk lokal yang sehat karena dibuat tanpa bahan kimia termasuk juga tanpa bahan pengawet makanan. Jika pengrajin memiliki langganan, maka seringkali langganan tersebut membeli di rumah pengrajin.

\section{Kelemahan (Weaknees)}

Hasil identifikasi tehadap kelemahan-kelemahan yang dihadapi produk kasoami ini adalah sebagai berikut: (a) Tidak memiliki system manajemen usaha yang baik, sehingga usaha kurang berkembang. (b) Tidak memiliki variasi bentuk termasuk kemasan produk tidak menarik, artinya tidak memiliki nilai jual karena masih menggunakan kemasan seadanya (sederhana), (c) Minimnya promosi produk, karena ciri khas industri kecil tidak memiliki dana yang cukup untuk promosi, (d) Wilayah distribusi masih terbatas disekitar pasar lokal yang ada di wilayah Wanci. Bila produk kasoami ini keluar hanya sebatas dijadikan sebagai oleh-oleh.(e) Modal yang dimiliki pengrajin minim, dan pengrajin kurang berani meminjam dibank karena khawatir tidak dapat membayar bunga pinjaman. (f) akibat selanjutnya adalah pengrajin hanya memiliki sarana dan prasarana yang minim sehingga kapasitas produksi yang dimiliki masih terbatas. Alasan lainnya adalah kurangnya tenaga kerja dan kekawatiran kasoami tidak laku dijual mengakibatkan kasoami yang dibuat jumlahnya tidak besar.

\section{Peluang (Oportunity)}

Bila mencermati peluang terhadap pengembangan produk ini, ada beberapa peluang yang perlu mendapatkan perhatian, antara lain: (a) Bertambahnya jumlah penduduk menyebabkan permintaan pasar tetap ada, karena kasoami ini sudah mulai dikenal bahkan digemari oleh masyarakat diluar warga Wakatobi, (b) Berkembangnya dunia internet yang dapat diakses dengan menggunakan handphone memungkinkan pengrajin untuk berjualan kasoami secara online, kenyataannya di lapangan adalah pengrajin kurang mampu mempromosikan produknya karena keterbatasan pengetahuan dan mereka kurang menyadari pentingnya membuat promosi secara online, (c) Bahan baku cukup tersedia, karena ubi kayu banyak ditemukan dan dapat dengan mudah tumbuh di Kelurahan Wanci. (d) Banyaknya agen distributor, tetapi selama pengrajin merasa cukup tenaga keluarga yang mereka miliki untuk memasarkan, mereka tidak akan menggunakan agen distributor.(e) Umumnya konsumen memiliki loyalitas yang tinggi, selama kualitas kasoami tetap dipertahankan apalagi ditingkatkan dan pelayanan yang baik diberikan maka konsumen akan tetap loyal pada pengrajin tersebut. (f) Pangsa pasar masih luas terutama untuk daerah-daerah di luar Kelurahan Wanci dan sangat memungkinkan jika produk kasoami tersebut dijual ke kota-kota lain di Sulawesi melalui agen distributor. Dan peluang lain adalah wisata di Kabupaten Wakatabi sedang berkembang dan wisatawan kemungkinan besar berkeinginan untuk merasakan makanan tradisional yaitu kasoami.

\section{Ancaman (Treath)}

Berdasarkan hasil identifikasi dan inventarisai ancaman yang dihadapi pengolah kasoami terungkap, sebagai berikut: (a) Kenaikan harga bahan bakar minyak sebenarnya tidak terlalu pengaruh, karena umumnya pengrajin menggunakan kayu bakar. (b) 
Dibukanya pasar bebas sekalipun memungkinkan produk makanan lain masuk, tetapi tidak terlalu berpengaruh pada pemasaran kasoami, masyarakat Wakataobi, khususnya Kelurahan Wanci lebih menyukai kasoami dicampur dengan ikan bakarnya dibandingkan makanan asing. (c) Perubahan cuaca yang tidak stabil kadang mengganggu produksi ubi kayu, (d) fluktuasi nilai rupiah tidak terlalu menggangu pemasaran kasoami, (e) begitu pula dengan pola hidup masyarakat Kelurahan Wanci yang mulai modern, tetapi mereka tetap menjadikan kasoami sebagai makanan pokok, (f) nasi sebagai produk substitusi tidak mempengaruhi pemasaran kasoami, karena minat masyarakat untuk membeli beras kurang.

Hasil perhitungan analisis SWOT menunjukan bahwa posisi usaha kasoami di Kelurahan Wanci berada pada Kuadran 3 dengan titik singgung IFAS (faktor strategi internal) dan EFAS (faktor strategi eksternal) adalah: $-0.13 ; 0.41$, dan ini dapat dilihat pada Gambar 1 berikut:

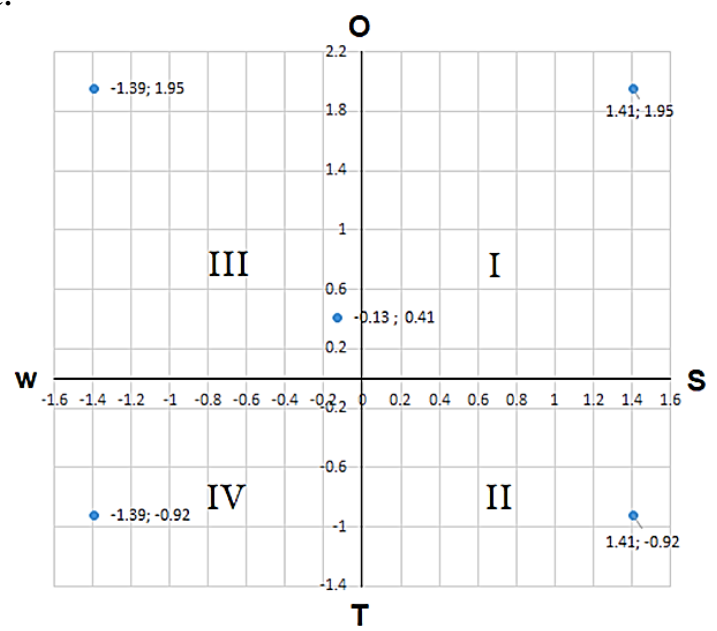

Gambar 1. Diagram Analisis SWOT

Pertemuan titik singguang IFAS dan EFAS berada pada kuadran 3, posisi ini menandakan kerajinan kasoami di Kelurahan Wanci berada pada posisi yang lemah namun sangat berpeluang untuk berkembang. Rekomendasi strategi yang diberikan adalah mengubah strategi, artinya pengrajin kasoami disarankan untuk mengubah strategi sebelumnya. Sebab, strategi lama dikhawatirkan sulit untuk dapat menangkap peluang yang ada sekaligus memperbaiki kinerja usahanya. Para pengrajin kasoami seharusnya mau belajar, memperbaiki cara pemasaran dan produk yang dihasilkan.

Strategi yang direkomendasikan berdasarkan hasil identifikasi dan inventarisasi kekuatan, kelemahan, peluang, dan ancaman terhadap usaha kerajinan kasoami di Kelurahan Wanci tersebut dapat dibuat tabel matriks analisis SWOT berikut: 
Tabel 1. Matriks Strategi Hasil Analisis SWOT Usaha Kasoami di Kelurahan Wanci Kecamatan Wangi-Wangi Kabupaten Wakatobi
Kekuatan
Kelemahan

\begin{tabular}{|c|c|c|}
\hline Peluang & 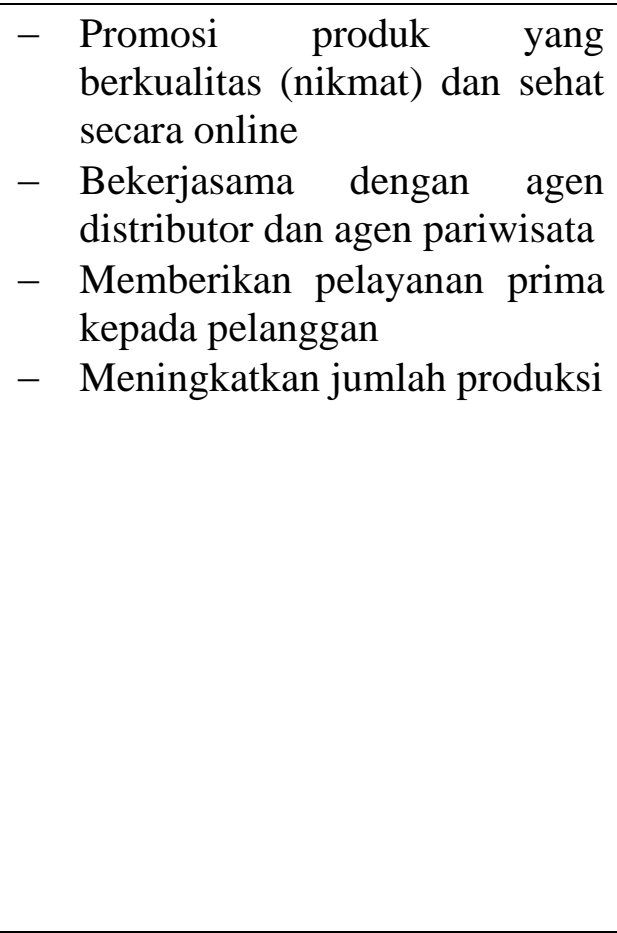 & 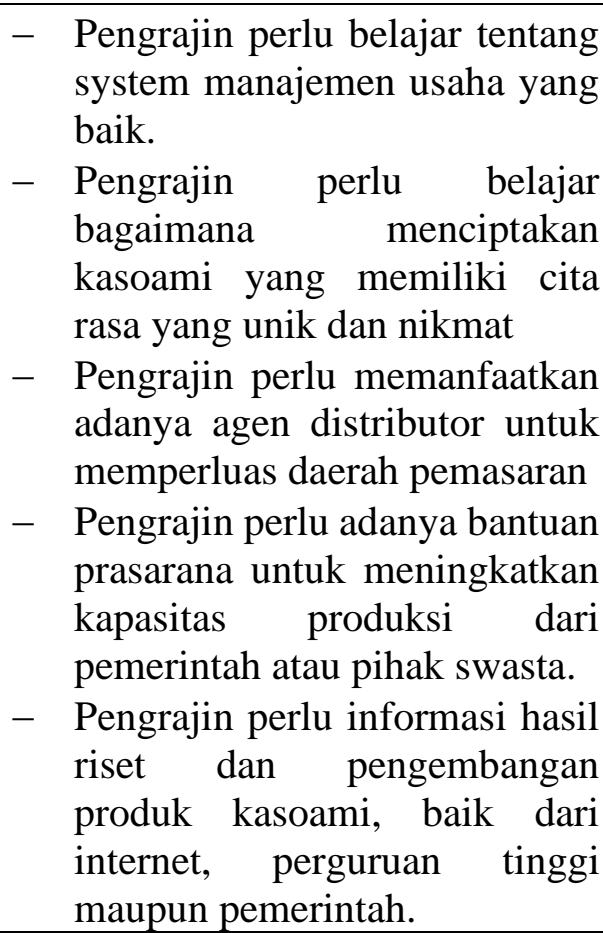 \\
\hline Ancaman & 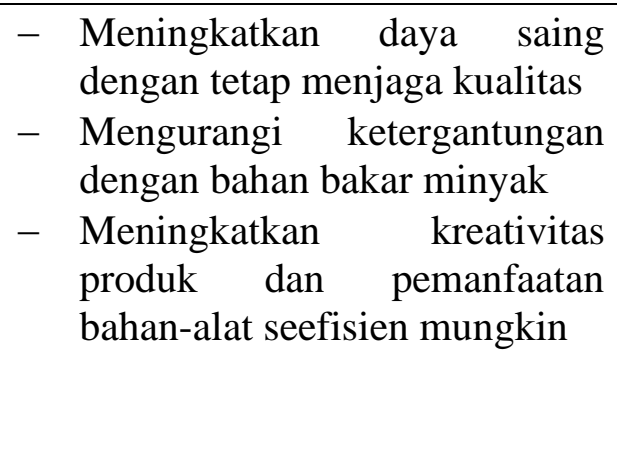 & 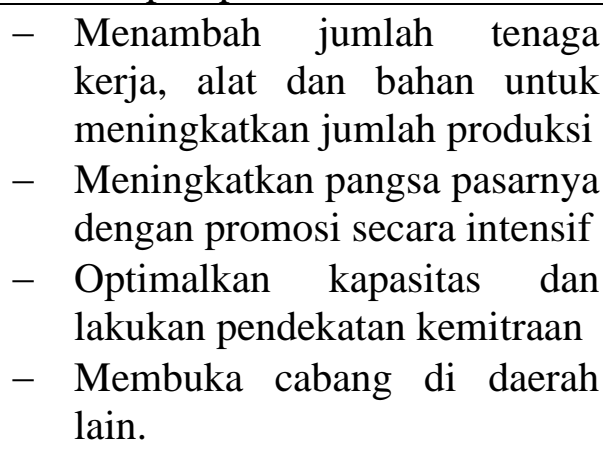 \\
\hline
\end{tabular}

\section{KESIMPULAN DAN SARAN}

\section{Kesimpulan}

Berdasarkan hasil penelitian dan pembahasan, maka dapat disimpulkan sebagai berikut: 1) Upaya-upaya yang dilakukan pengrajin kasoami dalam mempertahankan usahanya adalah belajar meningkatkan kualitas produk, umur simpan dan kemasan kasoami yang baik yang dilengkapi dengan label produksi sesuai standar yang berlaku; 2) Strategi pengembangan produk kasoami berdasarkan kekuatan dan peluang yang dimiliki pengrajin kasoami adalah (a) Mempromosi kasoami sebagai produk yang berkualitas (nikmat) dan sehat melalui media online; (b) Bekerjasama dengan agen 
distributor dan agen pariwisata, sehingga luas pemasaran kasoami meningkat; (c) Memberikan pelayanan prima kepada pelanggan (d) Meningkatkan jumlah produksi; Strategi pengembangan produk kasoami berdasarkan pemanfaatan peluang untuk menghadapi kelemahan yang dimiliki pengrajin kasoami adalah: (a) Pengrajin perlu belajar tentang sistem manajemen usaha yang baik; (b) Pengrajin perlu belajar bagaimana menciptakan kasoami yang memiliki cita rasa yang unik dan nikmat sehingga kasoami dapat dipasarkan lebih luas lagi; (c) Pengrajin perlu memanfaatkan adanya agen distributor untuk memperluas daerah pemasaran; (d) Pengrajin perlu mendapatkan bantuan prasarana untuk meningkatkan kapasitas produksi dari pemerintah atau pihak swasta. Strategi pengembangan produk kasoami berdasarkan kekuatan untuk menghadapi ancaman adalah: a) Meningkatkan daya saing dengan tetap menjaga kualitas; (b) Mengurangi ketergantungan dengan bahan bakar minyak; (c) Meningkatkan kreativitas produk dan pemanfaatan bahan-alat seefisien mungkin. Strategi pengembangan produk kasoami berdasarkan usaha untuk menghadapi kelemahan dan ancaman, adalah: (a) Menambah jumlah tenaga kerja, alat dan bahan untuk meningkatkan jumlah produksi; (b) Meningkatkan pangsa pasarnya dengan promosi secara intensif; (c) Mengoptimalkan kapasitas produksi dan melakukan pendekatan kemitraan pada agen distributor; terakhir (d) membuka cabang di daerah lain.

\section{Saran}

Perlunya keterlibatan berbagai pihak dalam pengembangan kasoami ini ke depan, seperti melibatkan perguruan tinggi, pemerintah daerah dan pihak perbankan. Terutama membantu dalam hal cara/metode pengemasannya, penganekaragaman produk turunan kasoami, membantu untuk mempromosikan dan memasarkan, serta yang tidak kalah pentingnya adalah bantuan dalam bentuk permodalan bagi pengrajin kasoami supaya bisa berkembang lebih baik lagi.

\section{DAFTAR PUSTAKA}

Amin, Haidir. 2006. Peningkatan Mutu dan Masa Simpan Kasoami Makanan Khas Tradisional Sulawesi Tenggara dari Bahan Baku Ubikayu (Manihot esculenta Crantz.). Tesis. Sekolah Pascasarjana Institut Pertanian Bogor, Bogor

Kotler, Philip. Dan Armstrong, Gary. 2008. Prinsip-prinsip pemasaran. Jilid 1. Edisi Keduabelas. Jakarta: Erlangga.

Marsigit, W. (2010). Pengembangan Diversifikasi Produk Pangan Olahan Lokal Bengkulu untuk Menunjang Ketahanan Pangan Berkelanjutan. Agritech. 30(4): 256-264

Singarimbun, M dan S. Effendi. 1989. Metode Penelitian Survei. Jakarta: PT. Pustaka LP3ES Indonesia. 